\title{
GELIAT HANGAT USAI PILPRES 2019
}

\section{Peresensi: M. Jamil ${ }^{1}$}

Indonesia sedang berada dalam salahsatu agenda nasional, yaitu Pemilihan Umum (Pemilu) serentak 2019. Pemilu serentak tahun ini dalam rangka pemilihan Calon Anggota Legislatif (baik DPRD Kabupaten/Kota, DPRD Provinsi, DPR RI), DPD RI, dan Pemilihan Capres dan Cawapres untuk masa baksi 2019-2024. Proses Pemilihan serentak sudah berlangsung pada hari Rabu, 17 April 2019, dan sesuai jadwal paling lama dilakukan pengumukan tanggal 22 Mei 2019 (karena rekapitulasi berjalan lancar, sehingga selesai sebelum batas akhir), rekapitulasi selesai pada tanggal 21 Mei 2019, lebih cepat satu hari sebelum batas akhir yang dijadwalkan.

Ada fenomena yang menarik sampai detik ini yang menyita perhatian publik, yakni terkait hasil Pilpres. Sesuai perhitungan nasional yang dilakukan Komisi Pemilihan Umum Republik Indonesia (KPU RI), Ir. H. Joko Widodo-Prof. Dr. KH. Ma'ruf Amin (Capres/Cawapres 01) memperoleh 85.607.362 suara atau 55,50 persen. Sedangkan perolehan suara H. Prabowo Subiyanto-H. Sandiaga Salahudin Uno (Capres/Cawapres 02) sebanyak 68.650.239 suara atau 44,50 persen. Selisih suara kedua pasangan mencapai 16.957.123 atau 11 persen.

Sejauh ini, penulis terus memantau proses Pemilu 2019, dari sebelum proses pencalekan, proses pencalekan, proses pemungutan suara, proses perhitungan suara tingkat TPS, proses rekapitulasi suara tingkat kelurahan/desa, proses rekapitulasi suara tingkat kecamatan, proses rekapitulasi suara tingkat kabupaten/kota, rekapitulasi tingkat provinsi maupun proses rekapitulasi tingkat nasional. Tiap peserta Pemilu (pasangan Capres, DPD RI, dan seluruh Parpol) biasanya mengirimkan saksi dalam tiap tingkatan perhitungan perolehan suara.

\footnotetext{
${ }^{1}$ Ketua Umum Pusat Studi Mahasiswa Pascasarjana (PUSMAJA) Mbojo-Yogyakarta Periode 2015-2017 | | Ketua II Bagian Eksternal Dewan Pimpinan Cabang Perhimpunan Mahasiswa Hukum Indonesia Daerah Istimewa Yogyakarta (DPC PERMAHI DIY) Periode 2012-2014 | Email: jamilncera@gmail.com | FB/Youtube/IG/Twitter: @MJAMILSH | Website: http://www.mjamil.my.id.
} 
Saat proses rekapitulasi tiap tingkatan, kalau ada selisih satu suara saja, pasti para saksi gontok-gontokan mempertahankan perolehan suara yang menjadi haknya. Kalau belum clear (belum selesai pembahasan) tingkat TPS, tidak akan mungkin bisa diproses rekapitulasi tingkat kelurahan/desa. Kalau belum selesai rekapitulasi tingkat kelurahan/desa, maka belum bisa dilakukan proses rekapitulasi tingkat Kecamatan. Kalau belum selesai rekapitulasi tingkat kecamatan, maka belum bisa dilakukan proses rekapitulasi tingkat kabupaten/kota. Kalau belum selesai rekapitulasi tingkat kabupaten/kota, maka belum bisa dilakukan proses rekapitulasi tingkat provinsi. Kalau belum selesai rekapitulasi tingkat provinsi, maka belum bisa dilakukan proses rekapitulasi tingkat nasional. Kalau kita memperhatikan proses setiap tingkatan, dan tentunya tiap peserta Pemilu mengirim saksinya, sangan kecil kemungkinan peluang oknum melakukan kecurangan.

Setelah ditetapkan Capres peroleh suara terbanyak, ternyata rivalnya tidak menerima akan hasil akhir yang telah ditetapkan oleh KPU RI. Sesuai prosedur yang dibenarkan hukum nasional kita, apabila keberatan atas hasil akhir rekapitulasi perolehan suara Pemilu serentak dapat mengajukan permohonan Perselisihan Hasil Pemilihan Umum (PHPU) tahun 2019 ke Mahkamah Konstitusi Republik Indonesia (MK RI).

Penulis mengapresiasi upaya yang akan dilakukan oleh pasangan Capres/Cawapres 02 untuk lakukan permohonan PHPU Pilpres 2019 di MK RI. Karena hal demikian merupakan upaya yang dibenarkan konstitusi kita di NKRI.

Biar pasangan Capres/Cawapres 02 bisa ditetapkan sebagai Presiden dan Wakil Presiden, setidak-tidaknya ini yang perlu dibuktikan.

Bila di taksir suara sah per TPS 250/TPS, dengan kisaran perolehan suara Capres/Cawapres 02 sebanyak 100\% dan perolehan suara Capres/Cawapres 01 sebanyak 0\% maka total TPS yang perlu dibuktikan kecuranggnya adalah 67.829 TPS, dengan total suara 16.957.123 (biar 02 lebih unggul 11 persen dari 01). Atau setidak-tidaknya harus mampu membuktikan kecurangan hingga mencapai keunggulan 51 porsen untuk suara Capres/Cawapres 02. 
Seharusnya, bila sudah ada inisiatif untuk permohonan PHPU Pilpres, maka dibarengi juga dengan ketidakperluan demo dijalan, karena hanya akan menambah panas suasana perpolitikan di bangsa ini.

Mari kita seluruh rakyat Indonesia kembali menyatu, demi bangsa dan negara kita tercinta, jangan biarkan bangsa kita menangis serta saling menghujat antara satu dengan yang lainnya.

Ketika ada ketidakpuasan dengan hasil akhir Pemilu, ada jalur-jalur yang diatur secara konstitusi untuk dilakukan upaya penyanggahan. Usai Pemilu, bila tidak puas, selanjutnya, yang tidak puas silahkan gontok-gontokan dalam upaya pembuktian di MK RI. Kerahkan seluruh daya, upaya, kekuatan untuk membuktikan bahwasannya telah terjadi kecurangan yang terstruktur sistematis masif.

Hasil yang diputuskan MK RI kelak, itu adalah hasil akhir yang juga menjadi kehendak mayoritas rakyat Indonesia. Oleh karenanya, yang menjadi hasil putusan MK RI seharusnya wajib kita amini bersama, jangan sampai adalagi demo berjilid-jilid karena itu hanya akan membuat gaduh bangsa ini. Akibat dari kegaduhan tersebut, banyak efek negatif yang akan timbul. Selebihnya, mari kita sama-sama membangun bangsa ini menjadi bangsa yang adil, makmur serta bermartabat.

Aturan main di negeri ini sudah jelas dan terang, tinggal kita kembali melihat konstitusi yang ada untuk menuntaskan perihal sengketa Pemilu 2019. Karena pada dasarnya menang dan kalah itu sudah menjadi garis takdir ilahi yang tak mungkin bisa disanggah, dan yang paling utama tak ada menang atau kalah yang sepadan dengan nilai persatuan dan kesatuan bangsa Indonesia. Jadi, mari kita rawat bersama bangsa ini dengan segala kebhinekaannya. 


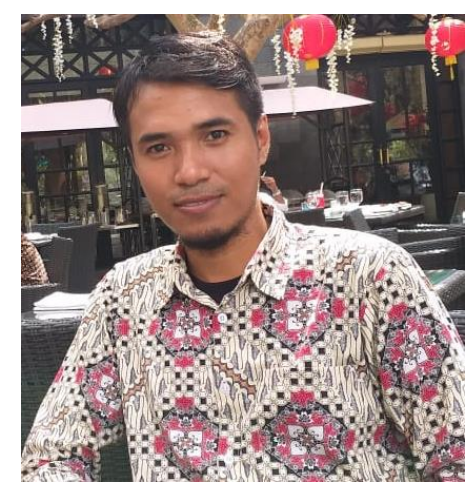

Penulis : M. Jamil, S.H.

Ketua Umum Pusat Studi Mahasiswa Pascasarjana (PUSMAJA) Mbojo-Yogyakarta Periode 2015-2017 | Ketua II Bagian Eksternal Dewan Pimpinan Cabang Perhimpunan Mahasiswa Hukum Indonesia Daerah Istimewa Yogyakarta (DPC PERMAHI DIY) Periode 2012-2014 | Ketua Ikatan Keluarga Alumni Prodi Ilmu Hukum Fakultas Syariah dan Hukum UIN SunanKalijaga Yogyakarta (IKASUKA Ilmu Hukum) Periode 2018-2023.

\section{Ful Sumber Tulisan:}

M. Jamil, “Geliat Hangat Usai Pilpres 2019”, dimuat di https://www.radarbangsa.com/opini/18418/geliat-hangat-usai-pilpres-2019, pada 29 Mei 2019, dan dimuat di http://ikasukaih.uinsuka.ac.id/id/kolom/detail/109/geliat-hangat-usai-pilpres-2019, pada 31 Mei 2019. 